\title{
Geçmişten Günümüze Yönetici Metaforlarının Analizi ${ }^{1}$
}

DOI: $10.26466 /$ opus.605482

*

\section{Hilal Erkol*}

* Doktora Öğrencisi, Ankara Üniversitesi Eğitim Bilimleri Enstitüsü, Ankara / Türkiye E-Posta: hilal-erkol@hotmail.com

ORCID: 0000-0001-6837-9887

\section{Öz}

Insan ve madde kaynağının belirli bir amaç için bir araya getirilmesini să̆layan kişi olarak tanımlanan "yönetici", tarihsel süreç içerisinde kendisini farklı toplumsal beklentileri karşılamak zorunda olan görevli konumunda bulmuştur. Bu değiş̧im okul yöneticilerin değisşen rol ve görevleri okul yöneticilerine yönelik üretilen metaforların da değişmesine neden olmuştur. Başlangıçta yalnızca eğitim öğretim sürecinden sorumlu olan kişi olarak tanımlanan yönetici tarihsel süreç içerisinde farklı metaforlar ile tanımlanmıştır. Bu nedenle çalışmanın amacı yönetici kavramının ilk kez kullanıldı̆̆ 20. yüzyıldan günümüze kadar gelinen süreçte okul yöneticilerine ilişkin üretilen metaforlarm analiz edilmesidir. Çalışmada geçmişte alanyazında yöneticilere yönelik üretilen metaforik algılara ve günümüzde yöneticilere yönelik üretilen metaforik algllara yer verilmektedir. Araştırmanın verileri yöneticilere ilişkin alanyazın incelemesi ile toplanmıştır. Çalışmada tarama modeli kullanılmıştır. Çalışma sonuçları yabancı alanyazın ve yerel alanyazın olmak üzere iki grupta ele alınmıştır. Yabancı alanyazın incelendiğinde, yönetici metaforlarının dönemin sosyal ve politik değişimlerinden etkilendiği görülmektedir. Oysa yerel alanyazın incelemesinde okul yöneticilerine yönelik otorite ve lider temalarının ön plana çıktı̆̆ı görülmektedir.

Anahtar Kelimeler: Okul yöneticisi, Metafor, Yönetici metaforları

\footnotetext{
${ }^{1}$ Bu makaleye katkılarından dolayı Prof. Dr. Ali BALCl'ya teşekkür ederim.
} 


\title{
An Analysis Of School Principalship Metaphors From Past To Present
}

\begin{abstract}
The manager defined as the person who brought human and material resources together for a specific purpose found himself in the position of being obliged to meet different social expectations in the historical process. This change led to changing metaphors for school principals' changing roles and duties. Initially defined only as the person responsible for the education process, the manager was defined by different metaphors in the historical process. So the aim of this study is to determine a metaphorical analysis of principalship from 20th century which principalship was first used to today. The study examined how the literature about the principalship viewed this position in the past from a metaphorical perspective as well as how the literature about the principalship viewed this position now from a metaphorical perspective. Data were collected by reviewing literature pertaining to the principalship. A survey model was used in this study. The results of the study were discussed in two categories as foreign literature and domestic literature. As foreign literature is examined, it is obvious that metaphors are shaped according to the socio-social events of the period while as domestic researches are examined it is seen that the dominant metaphors represent the authority representative and leader themes
\end{abstract}

Keywords: School principal, Metaphor, School principalship Metaphors 


\section{Giriş}

İnsan ve madde kaynağının belirli bir amaç için bir araya getirilmesini sağlayan kişi olarak tanımlanan "yönetici", tarihsel süreç içerisinde kendisini farklı toplumsal beklentileri karşılamak zorunda olan görevli konumunda bulmuştur. Bu durum yönetimin değişen dünya koşullarında farklı tanımlamalarının yapılmasının bir sonucudur. Nitekim Samier (2006), yönetimin yönetsel bir olgu olmaktan ziyade tarihsel bir konu olduğunu ve sistem teorisinde basitçe çevresel etmenler olarak görülen (sömürgecilik, toplumsal huzursuzluk, isyan, devrim ve eşitlik, yeni siyasi ve sosyal değerlerin ortaya çıkması gibi) pek çok etmenden etkilendiğini belirtmektedir.

Özellikle 1970'li yıllarda başlayan etkili okul kavramı yöneticilerden beklenen davranış rollerinin yeniden tanımlanmasına ve "etkili yönetici" kavramının doğmasına neden olmuştur. Yeterince iyi bir yönetici olmak (Institue for Educational Leadership, 2000) ya da örgüt amaçlarının gerçekleştirilme derecesi (Balc1, 2010) olarak tanımlanan etkililik kavramında önemli rol, koordinasyon gücüyle okuldaki işbirliğini sağlayan (Bursalığlu, 2005) yöneticiye verilmektedir. Bu durum başlangıçta yalnızca eğitim öğretim sürecinden sorumlu olan yöneticilerin tarihsel süreç içerisinde farklı roller (lider, araştırmacı, bilimsel yönetici, işbirliğini sağlayan kişi, vizyoner, disiplin sağlayıcı gibi) üstlenmelerini gerekli kılmıştır. Bu amaçla çalışmada yöneticilerin tarihsel süreç içerisinde değişen rollerine ve bu rollere ilişkin üretilen yönetici metaforlarına yer verilmektedir.

\section{Yönetici Metaforları}

Bu çalışmada öncelikle metafor ve okul yöneticisi kavramları tartışlarak eğitim yönetiminde bu kavramların önemine değinilmiştir. Daha sonra yurtdışı ve yurtiçi alan yazınında yer alan yönetici metaforlarına ilişkin çalışmalara yer verilmiştir. Alan yazın incelendiğinde yönetici metaforlarına ilişkin yurt dışı araştırmalarının tarihsel dönemler şeklinde ele alındığı görülmektedir. Konuya ilişkin yurt içi araştırmalarında ise çeşitli metaforların yer aldığı ve bu metaforların dönemsel olarak gruplandırılmasının mümkün gözükmediği görülmektedir. 


\section{Metafor}

Metafor (mecaz), bireyin farklı bir kavram ya da olguyu bütüncül ve ayrıntı11 bir şekilde anlamlandırma çalışması (Wagenheim, Clark ve Crispo, 2009), dünyayı kavramaya yarayan düşünme ve görme biçimi (Arnett, 1999; Morgan, 1998), yeni bir anlayışı ifade etme aracı (Bartel, 1983; Denshire, 2002; Palmquist, 2001), sosyal gerçekliğin mecazi olarak yansitılması (Balcı, 2010) olarak tanımlanmaktadır. Metafor kelimesinin kökeni Yunanca'da bir yerden başka bir yere götürmek anlamını taşıyan "metaphora" kelimesinden gelmektedir (Lakoff ve Johnson, 2010).

Metafor, doğrudan sorulan sorularla tanımlanması mümkün olmayan zihinsel bağlantıların ortaya çıarılmasında çağrıştırıcı rolü oynaması (Leavy, McSorley ve Bote, 2007) sebebiyle güçlü bir zihinsel haritalama yöntemidir (Arslan ve Bayrakçı, 2006; Zhao ve Zhou, 2010). Bu zihinsel haritalama yönteminin eski ve yeni edinilmiş bilgilerin anlamlandırılmasına fayda sağlayacak kavramlar geliştirilmesine imkan tanıdığı söylenebilir. Nitekim Massengill ve Mahlios (2008) metaforun; dünyayı, yaşamı ve mesleki kariyeri yorumlamada bilişsel bir araç olarak kullanıldığını ifade etmektedir.

Eğitimin analizinde ve planlamasında güçlü etkilere sahip olan metaforik düşünme (Martinez, Sauleda ve Huber, 2001) eğitim araştırmalarında da önemli bir yere sahiptir. Nitekim Bodycott ve Walker (2001) tarafından yap1lan araştırma sonuçları, okul yönetimi ve yönetim tarzı araştırmalarında metafor kullanımının örgütsel tutum ve inançlar hakkında geniş bilgi sağlamaya yardımcı olduğunu ortaya koymaktadır.

Eğitim araştırmalarında metafor kullanımında sıklıkla öğretmen ve öğretmen adaylarının mesleki algıları (Saban, 2004; Gürbüz ve Mevlüt, 2006; Cerit, 2008; Aydın ve Pehlivan, 2010; Shaw ve Mahlios, 2008; Eren ve Tekinarslan, 2013), okul (Saban, 2008; Nalçacı ve Bektaş, 2012; Özdemir, 2012; Strike, 2000), öğrenci (Saban, 2009; Çapan, 2010), müfettiş kavramı (Töremen ve Döş, 2009; Döş, 2010; Akan, Yalçın, Yıldırım, 2013; Tok, 2013) ve öğrenci velileri (Ünal, Yıldırım ve Çelik, 2010) konularına odaklanıldığı, okul yöneticilerine ilişkin metafor çalışmalarına sayıca daha sınırlı yer verildiği görülmektedir. 


\section{Okul Yöneticisi}

Değişen çevresel koşulların açık sistemler olan okulların değişimini zorunlu kılması, örgüt çevre ilişkilerinin yürütülmesinde anahtar rol oynayan yöneticilere bakış açısını ve dolayısıyla yönetici metaforlarını etkilemektedir. Nitekim okul yöneticilerine yönelik bakış açlarının tarihsel olarak incelendiği araştırma sonuçları (Goodwin, Cunnigham ve Eager, 2005; Kafka, 2009; Pierce, 1935; Rousmaniere, 2007) yaşanan dönemin sosyo-ekonomik olaylarının okul yöneticilerine yüklenen misyonu ve üretilen yönetici metaforlar1nı etkilediğini göstermektedir.

20. yüzyılın başlarında yönetici ve sekreterlik görevlerini yürüten okul müdürlerinin (Knezevich, 1969) zaman içerisinde artan rolleri güç ve etki kazanmalarına neden oluştur. Okul yöneticilerinin 1900'lü yılların sonunda okulun başında bulunan önemli ve güçlü kişiler olarak tanımlanmaları (Pierce, 1935; Rousmaniere, 2007) bu görüşü desteklemektedir. Pierce (1935) bu durumu şu şekilde ifade etmektedir:

Okulların ilk açıldığı yıllarda okullarda sadece öğretim faaliyetlerinin devam etmesinden sorumlu, genellikle okul yönetim kurulu tarafından seçilen ve yerel topluluğa karşı sorumlu bir öğretmen bulunmaktadır. 1800'lü yıllardan itibaren okulların büyümesi ile birlikte okul yöneticilerinin görev ve konumları da farklılaşmaya başlamış; okul yöneticilerine ders verme, disiplini sağlama, binanın korunmasını sağlama, okula devamı sağlama, derslerin zamanında başlayıp bitmesinin sağlama görevleri verilmeye başlanmıştır. Bu görevler okul yöneticilerinin otorite kazanmasını sağlamış ve zaman içerisinde okul yöneticileri sadece okulları uzaktan yöneten ilçe müfettişlerine hesap veren ve sorun ileten kişiler konumunda görülmeye başlanmıştır.

Pierce'in (1935) ifade ettiği üzere okul yöneticisinin zaman içerisinde görev ve konumunun farklılaşmaya başlaması, yetki alanının yeniden tanımlanmasına, 1970'lere kadar bina yöneticisi, öğrenci disiplinini sağlayan kişi gibi oldukça açık ve dar bir anlamda tanımlanan yöneticinin (Peterson ve Deal, 1998), 1800'lü yıllarda öğretim lideri (Balcı, 2007) olarak tanımlanmaya başlamasına neden olmuştur.

Yönetimsel verimlilik kavramının ortaya çıtığı 1900'lü yıllarda ise "etkili yönetici" olarak anılmaya başlayan (Goldring ve Greenfield, 2002) yöneticinin 21. yüzyıl itibariyle görev ve sorumlulukları eskisine göre çok daha 
karmaşık bir hal almış (Goodwin, Cunnigham ve Eager (2005), 21. yüzyıl yöneticisinin değişimi yöneten, esnek yapılar kurabilen, bilgi toplumu, küreselleşme, insan hakları gibi değerler doğrultusunda okulların varlık gerekçesini sürdürebilen (Özden, 1999), kurumsal lider, değişim ajanı, idareci, insan kaynakları yöneticisi, problem çözücü ve vizyoner (Leithwood, Harris ve Hopkins, 2008) özelliklerini taşıyan, yöneticilik görevlerini yüksek standart ölçülerine sahip hesap verebilirlik politikalarına göre yerine getiren (Harris, Ballenger ve Leonard, 2004; Kafka, 2009) kişiler olarak tanımlanmasina neden olmaktadır.

Şişman (2010) 21. yüzyıl okul yöneticilerinin rol ve sorumluluklarını teknik (kaynak sağlama, yöntem ve süreçleri belirleme, teknolojiden yararlanma) ve insani yeterlilik (örgütü çözümleme, örgütsel ve yönetsel sorunları belirleme, analiz etme ve sorun çözme gibi kavramsal ve çalışanları motive etme, çatışmaları yönetme, eşgüdüm sağlama) başlıkları altında ele almaktadır. Botha (2004) ise yöneticinin taşıması gereken özellikleri yaşamsal (profesyonel liderlik), önemli (işi sahiplenme ve katılım) ve gerekli (stratejik düşünme) olarak gruplandırmaktadır.

Yöneticilerin yerine getirmesi beklenen rol ve görevlerin çeşitliliği okul yöneticilerinin özellikle ortaöğretim kurumlarında liderlik görevlerini anlamada zaman sıkıntısı yaşamasına neden olmaktadır (Budhal, 2000). Okulları bir birinden farklı kılan özelliğin, yöneticilerin okulu yönetirken oynadıkları roller (Taymaz, 2009) olduğu göz önüne alındığında zaman sıkıntısının yönetici imajında önemli bir etmen olduğunu söylemek mümkün gözükmektedir.

Özetle, yıllar içerisinde okul yöneticisinin görevindeki değişmeler rolündeki değişmelere yol açmış ve bu rolün, başlangıç noktası olan sekreterlikten; örgüt mühendisliği, sosyal mühendislik, verim uzmanlığı, işletmecilik gibi aşamalara kadar gelmesine (Bursalıoğlu, 2008) neden olmuştur. Yıllar içerisinde değişmeyen ve artarak devam eden tek şey ise yöneticilerden beklenen davranış rolleri olmuştur. Nitekim Kafka (2009) az destekle büyük işler başarma ve herkes ile her şeyi olabilme becerilerinin tarih boyunca yöneticilerden beklenilen davranışlar olduğunu; bununla birlikte piyasa temelli bir çevrede toplumdaki sosyal ve eğitim eşitsizliği sorununun çözümünün yöneticilerden beklenmesinin son zamanlarda okul yöneticilerinin maruz kaldığ özel baskılardan biri olduğunu ifade etmektedir. 


\section{Yöntem}

Araştırma, tarama modelinde gerçekleştirilmiştir. Okul yöneticisi kavramının kullanılmaya başlandığı 1900'lü yıllardan 21. Yüzyıla kadar gelinen süreçte kullanılan yönetici metaforları on yıllık dönemler halinde incelenmiş ve dönemin baskın metaforları ortaya konulmaya çalışılmıştır. Dolayısıyla çalışma, betimsel bir araştırma özelliği göstermektedir.

Araştırmanın başlıca veri kaynaklarını, yurtdışında ve yurtiçinde okul yöneticilerine ilişkin yazılan kitaplar, tezler, makaleler oluşturmaktadır. Ayrıca metafor kavramının anlaşılmasının sağlanması amacıyla alan yazında başyapıt kabul edilen kaynaklardan yararlanılmıştır. Bu çerçevede çalışmada veriler, ilgili kaynaklardan taranmış ve betimlenmiştir.

\section{Bulgular ve Tartışma}

Tarama modelinde gerçekleştirilen bu araştırmada buğular yönetici metaforlarına ilişkin yurt dışı bulgular ve yönetici metaforlarına ilişkin yurtiçi bulgular şeklide iki alt başlık altında incelenmektedir.

\section{Yönetici Metaforlarına İlişkin Yurtdışı Araştırmalar}

Çalışmanın bu bölümünde 1920 yılından 2018 kadar gelinen süreçte alan yazında kullanılan yönetici metaforlarına ilişkin yurtdışı araştırmalara yer verilmektedir. Çalışmanın başlangıç noktası olarak 1920 yılının kabul edilmesinin nedeni ise bu tarihten önce Amerikan okullarında yönetici kavramının yer almaması ve yönetimsel olmayan (öğretmenlik) ve yönetimsel olan (yönetim ve kırtasiye işleri) bütün okul işlerinin öğretmenler tarafından yapılmasıdır (Linn, Sherman, ve Gill, 2007, 163). Çalışmada yurtdışı araştırmalar üç başlık altında ele alınmaktadır. Bunlar:

1. Beck ve Murphy (1993) tarafindan $1920-1993$ yılları arasında alan yazında yer alan yönetici metaforlarının 10 yıllık süreçler halinde incelendiğ $i$ çalışma sonuçları.

2. Monreo (2003) tarafından 1993-2000 yılları arasında alan yazında yer alan yönetici metaforlarının belirlenmesine yönelik yapılan çalışma sonuçları. 
3. 2000 yılı ve sonrasında yönetici metaforlarının belirlenmesine yönelik araştırmacı tarafından yapılan çalışma sonuçları.

Beck ve Murphy'in (1993) çalışması: Beck ve Murphy tarafından 1920 - 1990 yılları arasındaki yönetici metaforlarının incelendiği "Yöneticiliği Anlamak: Metaforik temalar, 1920'ler-1990'lar (Understanding the Principalship: Metaphorical Themes, 1920s-1990s)" adlı çalışmada, baskın yönetici metaforları 10 yıllık süreçler halinde ele alınmaktadır. Çalışmada yer verilen yönetici metaforları ve bu metaforlara ilişkin yöneticilerin taşıması gereken değerler şu şekildedir:

Ruhsal Lider (1920): Bu metafor, okul yöneticilerini, eğitim arzusuyla harekete geçen, bilimsel yönetim ilkelerinin rehberlik ettiği, onurlu ve önemli bir role sahip ruhsal liderler olarak tanımlamakta, okul yöneticilerinin topluma liderlik etmesi gerektiğini ve ortaya koydukları işin mutlak manevi değerlere sahip olması gerektiği görüşüne dayanmaktadır (Audinot, 1994; Monreo, 2003).

Bu metaforunun değerleri incelendiğinde; 1920'li yıllarda yöneticilik görevinin geleneksel ve manevi değerlerin temsilcisi olarak tanımlandığı ve okul yöneticilerinin topluma yol gösteren ruhsal liderler olarak görüldüğ̈̈ anlaşılmaktadır. Dikkat çekici bir diğer husus ise bu dönemde yöneticilerden bilimsel yönetim ilkelerini kendilerine rehber edinmelerinin beklenmesidir. Bu anlayışın verim, ekonomi, üretim gibi kavramların yönetim biliminin ilk yazarları tarafından yönetimde son amaç kabul edilmesinin ve bunun sonucu olarak Taylor'ın bilimsel işletmecilik akımının okul yönetimine girmesinin bir sonucu (Bursaloğlu, 2005) olduğunu söylemek mümkündür. Bununla birlikte bürokratik, yönetimsel, öğretimsel ve toplumsal sorumlulukları nedeniyle 1920'li yıllarda okul yöneticilerinin sahip olduğu statünün, 2000'li yıllarda sahip oldukları statü ile benzer özellikler gösterdiği görülmektedir.

Bilimsel yönetici (1930): Bu metafor; okul yöneticilerinin öncelikli görevinin yönetim olduğu, okul yönetiminin, okul düzeni ve bu kapsamda yapılan uygulamaların teftişi gibi yöneticilik eylemlerine dayandığı görüşünü desteklemektedir (Audinot, 1994, Monreo, 2003). Bu dönemde öğretim faaliyetlerinin denetlenmesi gibi yöneticilik görevlerinin ön plana çıarıldığı ve 
yönetimin öğretmenlikten ayrı bir meslek olarak ele alındığı görülmektedir. Bu anlayışın ortaya çıkmasında 1930'lu yılların eğitim yönetiminin okula uygulanmasının tanınmadığı bir dönem olmasının, bu dönemin yönetiminde yönetici hazırlama- yetiştirmenin nasıl olması gerektiğinin tartışıldığı ideolojik döneme (1820-1899) denk gelmesinin (Balc1, 2008) etkili olduğu söylenebilir.

Yönetimden çok yöneticiye güvenilmesi gerektiğini yönündeki fikirleri ile her alandaki yönetim yazarlarını etkilemiş olan Fayol 'un ve yapandan çok yapılacak işi ön planda tutan ideal tip bürokrasinin kurucusu Weber'in (Bursalığlu, 2005) de bilimsel yönetici metaforunun oluşumunda etkili olduğunu ileri sürmek mümkündür. Monreo (2003) ise bu on yıllık süreçte yönetimin öğretmenlikten ayrı bir meslek olarak tanımlanmasında, yöneticilerin konumuna vurgu yapmak ve okul yöneticilerinin okul liderleri yerine işletme yöneticileri olarak algılanmasının sağlanması amacıyla kurulan Ulusal Eğitim Derneği (NEA) gibi kuruluşların etkili olduğunu ifade etmektedir.

Demokratik lider (1940): Savaş süresince toplum lideri ve halkla ilişkiler temsilcisi olarak görülen okul yöneticileri1940'lı yıllar itibariyle, vatandaşların yetiştirileceği demokratik okulların liderleri olarak tanımlanmaktadır. Bu tanımlamada okulların yerine getirmesi gereken önemli sosyal amaçlara sahip oldukları düşüncesi etkilidir (Audinot, 1994, Monreo, 2003). Beck ve Murphy (1993) yöneticilerden bu rolleri yerine getirebilmeleri için eğitim programı geliştiricisi, grup lideri, koordinatörü ve denetleyici rollerini de yerine getirmelerinin beklendiğini ifade etmektedir.

Toplumsal olayların eğitim yöneticilerine yönelik üretilen metaforları etkilediği göz önüne alındığında demokratik lider metaforunun üretilmesinde 1939-1945 yılları arasında devam etmekte olan ve toplumların sosyolojik yapısı üzerinde büyük etkiler bırakan ikinci dünya savaşının etkili olduğunu söylemek mümkündür. Yönetici ve iş gören arasındaki iletişim kanallarının açı olması (Yörük ve Kocabaş, 2001), demokrasi ve insanın merkezde olduğu bir yönetim şekline sahip olması (Çelik, 2016), liderin örgütün amaç, plan ve politikalarının belirlenmesi sürecinde diğer grup üyelerinin fikir ve düşüncelerine önem vermesi (Tengilimoğlu, 2005) olarak tanımlanan demokratik liderlik 1940'li yıllarda okul yöneticisinin sergilemesi gereken rollerin bir bütününü oluşturmaktadır. Ayrıca bu metafor ile 1940'lı yıllarda ilk kez okulun siyasal rolüne vurgu yapıldığı söylenebilir. 
Teori rehberliğindeki lider (1950): Teori liderliğindeki rehber metaforunun değerleri incelendiğinde 1950'li yıllarda yeni bir yönetim anlayışının (Gedikoğlu, 1997) ortaya çıktı̆ıın söylemek mümkündür. Beck ve Murphy (1993) bu dönemde okul yöneticilerinden nitelikli olmalarının beklendiğini ve bu yıllarda ortaya çıkan teori hareketinin yönetici anlayışını yeniden şekillendirdiğini belirtmektedir. Bu beklentiyi karşlarken, yöneticinin öğretim ve yönetim ile ilgili becerileri bir araya getirmesi, bunu yaparken eğitim, psikoloji, sosyoloji ve ticari araştırmalardan elde ettiği bilgi ve teorileri kullanması, eğitimcilerin çalışmasını savunması ve eğitim uygulamaları eleştirilerine söz konusu uygulamaların etkililiğini gösteren ampirik araştırma verileri ile cevap vermesi beklenmektedir. Bu anlayış eğitim yöneticisinin farklı disiplinlerden; uluslararası alanda toplumsal etkinin artan rolü, teknolojinin artan etkisi, giderek daha karmaşıklaşan ve kalabalıklaşan okul ve okul sistemlerinin gelişimi, insan ilişkileri gibi konularda üniversite tabanlı eğitim kursları almasının gerekli olduğu görüşünü savunan teori hareketinin sonucudur (Beck ve Murphy, 1993).

Etkili bir yönetici olması, bu dönemde okul yöneticisinden beklenen bir diğer davranıştır. Bu davranışa ilişkin olarak okul yöneticisinin araştırmac1ları, okul ile ilgili araştırmalar yapmaya yönlendirmesi beklenmektedir. Okul yöneticisin zamanın etkin ve verimli kullanması da yöneticilerin önemli değerleri arasında yer almaktadır. Okul yöneticisinden görevlerini analiz etmesi, önceliklerini belirlemesi ve gerektiğinde iş ve sorumlulukların yerine getirilmesi için yetki paylaşımı yapması beklenmektedir (Monreo, 2003).

Bürokratik yönetici (1960): Güç ve sorumlulukları açıkça belirlenen okul yöneticilerinin bürokratik sistemin koruyucusu (hiyerarşi içindeki çeşitli güç dağılımlarını korumayan ve sisteme meydan okuyanlara karşı akıllıca siyasi yargılamalar yapan kişiler) olarak çalışması beklenmektedir (Beck ve Murphy, 1993, 88). Bu dönemde kullanılan kategorik, nicel, ampirik terimler, okul yöneticilerinin görevlerine yönelik tartışmaların artmasına yol açmış, okul yöneticilerinden planlama ve ölçme için daha sofistike, bilimsel yöntemler kullanmaları beklenmeye başlanmıştır. Bu dönemde okul yöneticilerinin aldıkları kararlarda ve uygulamalarında hesap verebilir olmaları hususunda artan baskılar ve siyasi talepler, okul yöneticilerinin kendilerini 
eleştirilmeye açık hissetmelerine ve rol beklentileri hususunda belirsizlik yaşamalarına neden olmuştur (Monreo, 2003)

Bürokratik yönetici metaforunun değerleri incelendiğinde okul yöneticiliğinin kişisel değerlerden arınmış, profesyonel bir meslek olarak algılanmaya başladığı ve okul yöneticilerinin bürokratik sistemin koruyucuları olarak tanımlanmaya başladığı görülmektedir. 1960'lı yıllarda yöneticilerin taşıması gereken değerler arasında en dikkat çekici olanı ise hesap verebilir olmalarıdır. Hesap verebilirliğe göre okul liderleri, okul sisteminin başarısı için açı, ölçülebilir hedefler ve öğrenmeyle ilgili standartlar oluşturmakla yükümlüdür (Balc1, 2011).

Lider yönetici (1970): Bu dönemde okul yöneticileri sadece öğretmenlere ve öğrencilere değil, daha büyük topluluklara liderlik yapması, insanlarla iyi ilişkiler kurması ve öğrenciler ve öğretmenler arasındaki pozitif etkileşimi kolaylaştırması beklenmektedir. Bunlara ek olarak, bu dönemde okul yöneticileri eğitimsel çabalara "anlam" kazandırmakla görevlidir ((Beck ve Murphy, 1993, Monreo, 2003).

Etkili okul araştırmalarının başladığı 1970'li yılların lider metaforunun baskın metafor olarak tanımlanmasında etkili olabileceğini söylemek mümkündür. Nitekim Balcı (2007) okul yöneticisinin okul etkililiğinde anahtar bir rol oynadığını ve okul yöneticisinin liderlik stili ve okul etkililiği arasında, gerçek bir ilişki olduğu konusunda görüş birliği olduğunu ifade etmektedir.

Öğretimsel lider (1980): Bu dönemde okul yöneticilerinden öğretmen ve öğrencilerin üretken öğrenme deneyimlerini yönlendiren, eğitim ve öğretim sürecinde ortaya çlkan sorunları çözen, eğitim öğretim sürecinin işleyişinin kolaylaştırılması için kaynak sağlayan, vizyoner, iletişime açık, okulun geleceği için ideal olan resimi geliştiren ve okulun vizyonunu korumak için gerekli değişiklikleri yapan öğretim liderleri olarak hizmet etmeleri beklenmektedir (Beck ve Murphy (1993).

Beck ve Murphy (1993) tarafından yapılan çalışma sonuçları 1920 -1990 yılları arasında okul yöneticilerine ilişkin kullanılan baskın metaforları ve bu metaforlara ilişkin değerleri ortaya koymaktadır. Toplumsal değişimlerin yönetici metaforları üzerindeki etkisi göz önüne alındığında 10 yıllık süreçler için kullanılan baskın metaforların 1920 - 1990 yılları arasında okul 
yöneticisi kavramına bakış açısını ve okul yöneticilerinden beklenen davranış rollerini anlamaya yardımcı olduğunu söylemek mümkündür.

Monreo'nun (2003) çalışması: Charles Edward Monroe tarafindan 2003 yılında Kuzey Carolina üniversitesinde yapılan “Yeni Milenyum'un Başlangıcında Yönetici Metaforlarının Analizi" adlı doktora tezinde, 1920 - 1990 yılları arasındaki yönetici metaforlarının incelenmesinde Beck ve Murphy tarafından 1993 yılında yazılan "Yöneticiliği Anlamak: Metaforik temalar, 1920'ler-1990'lar (Understanding the Principalship: Metaphorical Themes, 1920s-1990s)" adlı kitabın özetinden, 1993-2000 yılları arasındaki baskın metaforlarm belirlenmesinde ise Educational Administration Quarterly ve $\mathrm{Na}$ tional Association for Secondary School Principals Bulletin dergilerinden yararlanıldığı görülmektedir. Çalışmada 1993-2000 yılları arasındaki yönetici metaforların tanımlanmasında Monroe (2003) tarafindan kullanılan " Kurumsal lider, işbirlikçi, vizyoner, disiplin sağlayıcı ve değişim ajanı" metaforlarına yer verilmektedir.

- Öğretimsel lider: Beck ve Murphy (1993) tarafından yönetici rollerinin çerçevesinin çizilmesinde ahlak hizmetçisi, eğitimci ve toplum lideri metaforlarının 1990 ‘l yılların baskın metaforları olacağı iddia edilse de 1990'11 yılların baskın metaforu "öğretim lideri” olmuştur (Monroe, 2003).

Sınıf öğretimi, personel gelişimi ve müfredat geliştirilmesi gibi çeşitli görevlerin bir karışımı olarak tanımlanan (Smith ve Andrews, 1989) öğretimsel liderlik özelliklerini benimseyen okul yöneticilerinin sergiledikleri; öğretmenlerine danışmanlık yapma, mesleki araştırmalar yapma, okul içerisindeki çalışmalarda takım kurma, problem çözme ve belirsiz konularda öğretmenlerine gerekli açıklamalarda bulunma davranışlarınun (Glanz ve Neville, 1997), öğretmenlerin duygusal, bilişsel ve davranışsal tutumları üzerinde olumlu etkileri bulunmaktadır.

Blase ve Blase (1999) ̈ğretimsel lider olarak okul yöneticilerinden; yönetim sürecinde çeşitli stratejileri kullanmalarının, öğretmenlerin mesleki gelişimini teşvik etmelerinin (eğitimciler arasında işbirliğini ve danışmanlık ilişkisini, programların yeniden tasarımını, eylem araştırmaların teşvik etmek ve desteklemek, modelleme yapmak ve öğretmenlerden tavsiye ve görüş talep etmek gibi) beklendiğini ifade etmektedir. Ovando ve Cavozos (2004) ise öğretmenleri öğrencilerin akademik he- 
deflerini geliştirmek ve uygulamak; okul kültürünü şekillendirmek ve öğretim programını yakından izlemek için yetkilendirmelerinin öğretimsel lider olarak yöneticilerden beklenen davranışlar olduğunu vurgulamaktadir.

Söz konusu yönetici davranışları göz önüne alındığında öğretimsel liderlik metaforunun yöneticilere katalizör görevi yüklediği görülmektedir. Okul yöneticisinin mesleki anlamda kendini geliştirmesi ve liderlik vasıflarını taşıması yeterli görülmemekte, okul kültürünü, öğretmenlerin mesleki gelişimini ve öğrenci başarısının da desteklemesi beklenmektedir. Bu metaforun yöneticilere yüklediği en önemli rol ise, hesap verebilir olma davranışıdır. Öğretimsel liderlik metaforu akademik performans için öğretmenin (Ovando ve Cavazos, 2004) ve okul yöneticisinin hesap verebilir olmasına vurgu yapmaktadır. Firestone ve Riehl ( 2005) ve Heinrich (2009) “Hiçbir Çocuk Geride Kalmasın (No Child Left Behind)" hareketi ile ortaya çkan hesap verebilir olma durumunun bu metaforun halen etkin olmasında önemli bir role sahip olduğunu ifade etmektedir.

- İşbirlikçi: Bu metafor okul yöneticilerinin öğretmenlerini mesleki gelişimleri konusunda desteklemesi gerektiği görüşüne dayanmaktadır. Nitekim Ash ve Persall (2000) okul yöneticisinin öğretmenlerini mesleki gelişimleri hususunda teşvik ederek, öğretmenlerinin mükemmellik arayışında onları destekleyen bir çevre oluşturmaları gerektiğine vurgu yapmaktadır. Bu çevrenin oluşturulmasında okul yöneticisinin öğretmenleri ile gerçekleştireceği iletişim önemli rol oynamaktadır. Bredeson (1987) iletişimin liderliğin kalbi olduğunu ve okul yöneticisinin başarılı olabilmesi için bu metaforun anlamına odaklanması gerektiğini ifade etmektedir.

- Nwagwu (1998), okuldaki öğretim sürecinin en iyi şekilde gerçekleştirilmesi için bir komite kurma, okulda yapıcı bir rehberlik programı geliştirme ve bu gelişimi teşvik etme, öğretim stratejileri ve bu stratejilerin uygulanmasında karşılaşılan güçlükler ve çözüm önerileri üzerine tartışmalar düzenleme, öğretmenlerini profesyonel örgütlere katılımı konusunda destekleme, onların konferanslara, çalıstaylara ve forumlara katılımını destekleme, sınıf problemleri ve öğretim stratejileri gibi konularda etkinlikler planlama faaliyetlerinin işbirliği yapan kişi olarak 
okul yöneticisinin yerine getirmesi gereken davranışlar olduğunu ifade etmektedir.

İşbirlikçi metaforunun öğretimsel liderlik özellikleriyle benzerlik gösterdiği görülmektedir. Okul yöneticisinin okulda demokratik bir ortam oluşturarak; okulun paydaşlarını karara katması, onların mesleki gelişimini desteklemesi, liderlik davranışları sergilemesi ve öğretimsel sorunlara ortak çözümler bulması beklenmektedir.

- Vizyoner: Bu metafor okul yöneticisinin bir vizyona sahip olması ve okulun paydaşların bu vizyona inandırması hususuna odaklanmaktadır. Nitekim Hallinger ve Heck (1996) okul yöneticisinin sahip olduğu vizyonun öğretmenler ve öğrenciler üzerinde etkili olduğunu ve öğretmen ve öğrencilerin başarısını etkilediğini ifade etmektedir. Lord ve Brown (2001) okul yöneticisinin diğerleri üzerindeki olumlu güdüleme etkisinin yöneticilerin izleyenler üzerinde yarattı̆̆ ideal öz benlik ile ilişkili olduğunu (örneğin bir iş görenin en fazla arzuladığı öz imajına ilişkin) ifade etmektedir. Stam, Knippenberg ve Wisse (2010) ise izleyen odaklı vizyonun (izleyenleri şahsi olarak takip ederek ve onları vizyona dahil ederek) ideal öz benlik yaratımını daha mümkün kıldığını ifade etmektedir. Sonuç olarak alan yazında hangi yaklaşımın izleyenler üzerinde daha etkili olduğu hususunda bir görüş birliği bulunmamaktadır. Bununla birlikte örgüt yöneticisinin vizyoner liderlik özellikleri sergilemesi ve izleyenleri tarafından paylaşlan bir örgüt vizyonu oluşturması gerekmektedir. Nitekim Frese, Beimel ve Schoenborn (2003) liderin örgüt değerlerinin ve temel görevlerinin bilincinde olduğunu ve oluşturulan örgütsel vizyonun izleyenlere ilham vermesi ve onları motive etmesi gerektiğini ifade etmektedir.

- Disiplin sağlayıcı: Okullar genellikle öğrencilerin uygunsuz davranışlarını önlemeye ve azaltmaya yönelik bir eğitim politikasına sahiptir. Okul yöneticisinin görevi ise bu politikaya uygun olarak öğrencilere yaptırım uygulamaktır. Nitekim Skinner, Skinner, Skinner ve Cashwell (1999) çoğu yöneticinin okuldaki uygunsuz öğrenci davranışlarını önlemek için proaktif programlar tasarladığını belirtmektedir. Bu bağımsız grup odaklı programlar genellikle okul kurallarını çiğneyen öğrencilere yaptırım uygulamakta, ardından okul yöneticileri, öğretmenler ve öğrenciler bu uygunsuz davranışlara tepki vermektedir. Bu davranış okul yöneticisinin disiplin sağlayıcı rolünü desteklemektedir. 
- Değişim ajanı: Değişim, örgütler için zor ve sancllı bir süreçtir. Bu sürecin başarıyla atlatılabilmesi için yöneticinin vizyoner, kültürel, etik, dönüşümsel, liderlik gibi pek çok liderlik türünü bilmesi ve bunları bir arada uygulayabilmesi gerekmektedir (Özmen ve Sönmez, 2007). Monreo (2003) değişim ajanı metaforunun değişim ve altı temel inançla (kişisel mücadeleye değer verme, tüm insanların onurunu tanıma, kişiliği ve mesleği birbirine uyumlama, insanların ellerinden gelenin en iyisini yapacaklarına inanma, dinleme ve hayal etme) birbirine bağlı olduğunu, bu nedenle önemli bir metafor olduğunu ifade etmektedir.

2000 yılı ve sonrası çalışmalar: 2000 yılı ve sonrasına yönelik yapılan alanyazın taramasında yönetici metaforlarının daha çok yöneticilerin kişilik ve liderlik özelliklerine odaklandığı görülmektedir. Bu çalışmaların bir kısmına aşağıda yer verilmektedir.

- Day, Harris, Hadfield, Tolley ve Beresford (2000): Yöneticilere, öğrencilere, öğretmenlere ve siyasilere liderlik metaforlarının sorulduğu çalışma sonucunda yöneticiler için en sık kullanılan metaforların "annebaba, baba, anne" metaforları olduğu görülmektedir. Araştırmacılar tarafından bu sonucun nedeni okul için en sık kullanılan metaforun "ev" olması olarak açıklanmıştır. Araştırma sonucuna göre okul yöneticileri için en sık kullanılan diğer metafor ise "elindeki tüm tabakları aynı anda döndüren hokkabaz" metaforudur. Küçük bir grup ise yöneticileri "yumruk torbası" olarak tanımlamaktadır.

- Linn, Sherman ve Gill (2007): Geleceğin liderlerinin yöneticilik algısının metafor aracılığıyla incelendiği "Eğitim Liderliğini Anlama: Yönetici metaforları (Making meaning of Educational Leadership: The Principalship in Metaphor)" adlı araştırmanın çalışma grubunu bir üniversitenin yönetici hazırlama programına katılan 41 yönetici adayı oluşturmaktadır. Araştırma sonucunda koruyucu ve besleyici; yetenekli, gözü kara ve problem çözücü; rekabetçi, risk alan; değişim ve şans olmak üzere dört temanın ortaya çıktığı görülmektedir. Linn, Sherman ve Gill (2007) tarafından bu temaların anlamları şu şekilde açıklanmaktadır.

Koruyucu ve besleyici temasında en sık kullanılan metafor "bahçıvan" metaforudur. Bahçıvanlık zor bir iştir, fakat ödülü bütün çabalara değmektedir. Yöneticilik görevi için de aynı durum söz konusudur. Ayrıca okul 
yöneticiliğinin zor bir iş olduğu ve bu nedenle okul yöneticisinin yetenekli, gözü kara ve başarılı bir problem çözücü olması gerektiğine vurgu yapılmaktadır. Rekabetçi ve risk alan teması ise oldukça ilginçtir. Çünkü yönetici adayları rekabet ve riskin yöneticinin sıklıkla karşılaşabileceği durumlar olduğunu ifade etmektedir. Değişim ve şans teması ise yöneticiliğin kontrol edilmesinin ve tahmin edilebilmesinin imkansız olduğu görüşüne dayanmaktadır.

- Trnavcevic ve Voupot (2009): Yönetici adaylarının okul yöneticiliği kavramına ilişkin algilarının incelendiği "Görevini severek yapan yöneticilerin yöneticilik algılarını açıklamak (Exploring aspiring principals' perceptions of principalship)" adlı çalışma sonuçları okul yönetici adaylarının; örgütsel görevlere, planlama ve kontrol üzerine odaklanan bir yönetici figürü algısına sahip olduğunu göstermektedir. Yöneticilik görevinin alan yazında öğretimsel ve dağıtımsal liderlik ile ilişkilendirmesine rağmen yönetici adayları tarafından yönetim ile ilişkilendirildiğini ifade eden Trnavcevic ve Vaupot (2009) yönetici adayları tarafından gücün önemli görüldügünü ifade etmektedir. Ayrıca araştırmada yöneticilerin örgütsel görevler, planlama ve kontrol üzerine odaklanması gerektiği hususundaki yönetici görüşlerine de yer verilmektedir. Çalışmada yönetici adayları tarafindan ataerkil, merkeziyetçi, güç ve kontrole dayalı metaforların üretildiği ve bu metaforların "Yetki kaynaklı güç (anne, baba, ailenin yaşlı üyesi, tavuk ve civcivler, büyük diktatör, süpermen ve patron)" ve "Yoyo ve politikacilar (manevra, esnek, yoyo, yumuşak başlı, duruma göre değişen)" temaları altında incelendiği ifade edilmektedir.

- Polat (2013) : Öğretmenlerin görüşlerine dayalı olarak okul yöneticisi kavramını metaforik olarak inceleyen araştırmanın çalışma grubunu 127 öğretmen oluşturmaktadır. Çalışma sonuçları yöneticilerin olumlu ve olumsuz metaforlara sahip olduğunu, klasik yönetici davranışlarının öğretmenler tarafından olumsuz; modern yönetici davranışlarının ise öğretmenler tarafından olumlu metaforlar üretilmesine neden olduğunu göstermektedir. Ayrıca çalışma sonuçları öğretmenlerin okul yöneticisini algılama biçimlerinin var olan durumu tanımlama, koruma ya da değiştirme davranışında etkin olduğunu göstermektedir.

- Schechter, Shaked, Ganon-Shilon ve Goldratt (2016): Liderlik metaforları: Okul yöneticilerinin ulusal reformları anlamlı kılması (Leadership 
metaphors: school principals' sense-making of a national reform)" adlı araştırmanın çalı̧̧ma grubunu 59 ilköğretim okul yöneticisi oluşturmaktadır. Eğitim alanında yapılan reformlarda okul yöneticilerinin belirsizlik, çelişen istekler ve eksik bilgilendirilme durumu ile sık sık karşı karşıya geldiğini ifade eden Schechter ve diğerleri (2016) araştırma sonuçlarının yeniden çerçevelendirilen yöneticinin rolleri, yöneticinin işi ve yöneticilerin öğretmenler ile ilişkisi üzerine odaklandığını göstermektedir. Çalışma sonuçları yöneticilerin değişim ajanı ve sistem oyuncusu olarak reformları yorumlayarak ve anlamlandırdığını ve okullarında uyguladıklarını ortaya koymaktadır. Bununla birlikte, reformların uygulanmasında yerel yönetimlerle işbirliği yapması gereken yöneticilerin örgüt politikalarında aktif yönetici metaforunu; yukarıdan aşağıya doğru programlama yapılan daha mekanik işlerde kukla metaforunu tercih ettikleri ifade edilmektedir. Araştırmada yöneticiler tarafından aynı problemin farklı anlamlandırıldığını ve bu durumun yöneticilerin mesleki kültürlerini oluşturan değer ve inançlar ile ilgili olduğu vurgulanmaktadır.

- Konan ve Yılmaz (2017): İlkokul okul yöneticilerinin okul yönetimine ilişkin algılarının metaforik olarak incelendiği çalışma sonuçları ilkokul yöneticilerinin genel olarak kendilerine ilişkin olumlu bir algıya sahip olduklarını göstermektedir. Konan ve Yılmaz (2017)'a göre bu olumlu alg1 okul yöneticilerinin yönetimi; bütünleşme ve uyum, yönetim ve rehberlik, güdüleme ve etkililik, patriarşi kavramları ile özdeşleştirmesinden kaynaklanmaktadır. Bununla birlikte okul yöneticilerinin kendilerine ilişkin olumsuz metaforlar da ürettikleri görülmektedir. Konan ve Yılmaz (2017) bu durumun yöneticilere yüklenen araştırmacl, denetmen, mentör, eğitimci, yönetici, koç, yönetmen, lider, anne/baba, bakıcı, otorite, kral, patron, bahçıvan, hakim gibi rollerden kaynaklandığını belirtmekte ve araştırmalar ve seminerler aracılığıyla bu olumsuz algının değiştirilebileceğini ifade etmektedir.

Özetle, yönetici metaforlarına ilişkin yurtdışı alan yazını incelendiğinde, metaforların yaşanan dönemin sosyo-toplumsal olaylarına göre şekillendiği, 1920'lerde ruhsal lider olarak tanımlanan yöneticinin, 1930'lu yıllarda bu özelliğini kaybederek ve bürokratik özellikler kazandığı, 1940'larda yönetici metaforlarının demokratik bir çerçevede yeniden değer ve inançlarla ilişkilendirildiği görülmektedir. 1950'li yıllarda başlayan teori hareketi ile siyasi 
ve akademik çevrelerin okul çevre ilişkilerine etki etmeye başlaması, yöneticiliğin yeniden tanımlanmasına neden olmuştur. Bu süreci 1960'larda yöneticiliğin öğrenilebilen bir meslek olduğu görüşüne dayanan ve yöneticiyi sistemin koruyucusu olarak tanımlayan "Bürokratik yönetici" metaforu izlemiştir. 1970'lerde ise eğitim yöneticisine eğitim çabalarına anlam yükleme görevi yüklenmiştir. 1980'li yıllarda 1920'lerde olduğu gibi yöneticinin sadece okulun değil, toplumun da lideri olduğu görüşü yeniden gündeme gelmiş, bu dönemde okul yöneticileri için öğretimsel lider metaforu kullanılmıştır.1980 sonrası üretilen yönetici metaforlarının da (vizyoner, işbirlikçi, disiplin sağlayıcı, değişim ajanı) öğretimsel liderlik değerlerini taşıdığı görülmektedir. 2000'li yıllar ve sonrasında yapılan sinırlı sayıdaki çalışmalar ele alındığında ise sınırları bürokratik çizgilerle çizilmiş, güç ve kontrole dayalı yönetici ve değişim ajanı ve sistem oyuncusu olarak reformları yorumlayan ve anlamlandıran yönetici olarak iki farklı yönetici metaforunun ortaya çıktığı görülmektedir.

\section{Yönetici metaforlarına ilişkin yurtiçi araştırmalar}

Çalışmanın bu bölümünde Türkiye'de yapılmış olan yönetici metaforları çalışmalarına ve bu çalışmaların sonuçlarına yer verilmektedir. Türk Eğitim Sisteminde kullanılan yönetici metaforlarına ilişkin yapılan alan yazın taramasında yedi makaleye ve üç tez çalışılmasına ulaşılmıştır.

Cerit (2008) tarafından öğrenci, öğretmen ve yöneticilerin müdür kavramina ilişkin görüşlerinin incelenmesi amacıyla 600 öğrenci, 203 öğretmen ve 51 yönetici ile yapılan araştırma sonuçları öğretmen ve yöneticiler tarafından çoğunlukla "araştırmacı, kontrol eden kişi, danışman, eğitim uzmanı, yönetmen, koç, orkestra şefi ve lider" metaforlarının kullanıldığını, "anne/baba, bakıcl, otoriter kişi, kral, patron, bahçıvan ve hakim" metaforlarının daha az kullanılan metaforlar olduğunu belirtmektedir. Cerit (2008) "danışman, eğitim uzmanı, koç ve orkestra şefi" gibi metaforların kullanılmasının müdürlerin eğitim-öğretim etkinliklerinin niteliğini artıran, okuldaki insan ve madde kaynaklarını organize eden, öğretmen ve öğrencilere ihtiyaçları olduğunda yardımcı olan ve rehberlik eden kişiler olarak alg1lanmasının; "otoriter kişi, kral, patron ve hakim" gibi metaforların kullanılmasının ise müdürlerin okullarda tek güç sahibi ve bütün kararların alıc1- 
Sı olan ve aldıkları kararlara itaat edilmesini isteyen kişiler olarak görülmesinin etkili olabileceğini ifade etmektedir.

Dönmez (2008) tarafından Türk Eğitim Sisteminde kullanılan yönetici metaforlarına ilişkin yapılan tez çalışmasında "kaynaştırıcı, danışman, anne-baba, koruyucu kurtarıcı, aile bireyi, aile reisi, muhasebeci, güvenlikçi, bilgisayar mouse'u amortisör ve şamar oğlanı" metaforlarının Türk Eğitim Sisteminde en sik kullanılan metaforlar olduğu ifade edilmektedir.

Yıldırım ve Uğur (2011) tarafından 4 anaokulu, 25 birinci kademe, 25 ikinci kademe, 12 ortaöğretim ve 15 üniversite öğrencisi ile yapılan araştırmada; ilköğretim birinci kademe öğrencileri tarafından üretilen 15 metaforun 12'sinin; ilköğretim ikinci kademede (5-8) bulunan öğrenciler tarafından üretilen 39 metaforun $29^{\prime}$ unun ve ortaöğretim öğrencileri tarafından üretilen 39 metaforun 29 'unun olumsuz olduğu görülmektedir. Çalışmada ilköğretim ikinci kademe öğrencilerinin okul müdürleri için en sık kullandıkları metaforların "çok sert, sinirli, kuralcı, yasakçı, kaba konuşan, öğrencilerle konuşmayan, yüzü gülmeyen, çatık kaşlı, kalın sesli, göbekli ve kilolu", ortaöğretim öğrencilerinin en sık kullandıkları metaforların ise "yasakçı, para toplayan, kuralcı, otoriter, yaşlı, ayrıcalık yapan birileri" olduğu görülmektedir.

Koçak (2011) tarafından yapılan “Okul müdürlerinin; öğrencilik, öğretmenlik ve müdürlük dönemlerindeki okul yöneticiliğine ilişkin metaforik algıları" adlı tez çalışması sonuçları okul müdürlerinin öğrencilik dönemlerinde okul yöneticiliğine ilişkin ürettikleri metaforların okul yöneticiliğini sert, otoriter, baskıcı, korkutucu ve ulaşılamaz olarak yansıttığını; öğretmenlik dönemlerinde okul yöneticiliğine ilişkin ürettikleri metaforların okul yöneticiliğini yönlendiricilik ve liderlik ile gereksiz bir makam olarak yansittığını ve müdürlük dönemlerinde okul yöneticiliğine ilişkin ürettikleri metaforların okul yöneticiliğini lider, koruyucu ve sorun çözücü olarak yansıttığını göstermektedir.

Yalçın (2011) tarafından ilköğretim okullarında okul müdürüne ilişkin metaforik algıların öğrenci, öğretmen, veli ve yönetici bakış açısıyla incelendiği tez çalışması sonuçları ise "baba, aslan, aile reisi, karınca, anne-baba, çiçek, lider, ağaç, gemi kaptanı ve güneş" metaforlarının okul yöneticilerine ilişkin en fazla üretilen metaforlar olduğunu ortaya koymakta ve üretilen bu metaforların öğrenci, öğretmen, veli ve yönetici bakış açısından değişiklik gösterdiğini ifade etmektedir. 
Turhan ve Yaraş (2013) tarafından 50 sınıf öğretmeni ve 110 ilköğretim birinci kademe öğrencisi ile yapılan araştırma bulgularl; okul müdürlerinin, öğretmenler ve öğrenciler tarafından güvenilir, güce sahip ve lider, çalışkan ve bilgili, denetleyici, düzenleyici ve yol gösterici ve hayatî bir unsur olarak algılandıklarını göstermektedir. Öğrenciler tarafından okul müdürüne ilişkin olarak en çok "Baba" metaforu kullanılırken; öğretmenler tarafından okul yöneticisi için en çok "Hakem" metaforunun kullanıldığı ifade edilmektedir.

Baştan, Tetik ve Kasımay (2014) tarafından okul müdürlerinin "müdür" kavramına yönelik algılarının incelendiği çalışmada "baba, beyin, arkadaş, anne, merkez, google, arkadaş, çiftçi, bir, ebru sanatı, adamın dibi, biz, vitrin, psikolog, sosyolog, ressam, lider, çatı, okul, gökkuşağı, şanzıman, köprü, çerçeve, lokomotif, kraliçe arı (beğ), kaptan, teknik direktör, muson yağmurları" metaforlarının olumlu; "hamal, yamalı lastik, ikinci eş, hiç, işçi, sırtında dağ taşıyan hamal, dilenci" metaforlarının olumsuz; "tarak, yumurta, şey, çerçeve, sabır taşı, kolsuz ressam" metaforlarının ise hem olumlu hem olumsuz anlamda kullanıldı̆̆ı görülmektedir. Örücü (2014) ise çalışmasında yöneticilere yönelik üretilen metaforların yoğunlukla yöneticilerin sert, otoriter, kararlara katılımı desteklemeyen, güç kaynaklarını ve yetkilerini genellikle hiyerarşik düzen içinde kullanan, bazen abartılı bir biçimde baskıcı, kuralcı, disipline dayalı otorite ve kontrol mekanizmalarını yürüten kişi özelliklerine vurgu yapıldığın ifade etmektedir.

Akan, Yalçın ve Yıldırım (2014) tarafından yapılan çalışmada öğretmenler tarafından müdür kavramına ilişkin geliştirilen metaforların çoğunlukla yönetim kavramına ilişkin olduğunu (komutan, asker, bilgisayar, kalem, yönetici, orkestra şefi); bu durumun yöneticilerin, okullarda tek güç sahibi ve bütün kararların alıcısı olan ve aldıkları kararlara itaat edilmesini isteyen kişiler olarak algılanmalarının bir sonucu olduğunu ifade edilmektedir. Araştırmanın bir diğer sonucu olan bilgi aracı olarak okul yöneticisi (bilgisayar, kalem, güneş, billboard) metaforu ise araştırmacilar tarafından okul yöneticilerinin davranış biçimlerindeki değişimin yansıması olarak yorumlanmaktadır.

Gökçe ve Bülbül (2014) tarafından meslek lisesi öğrencileri ile yapılan çalışmada ise okul müdürlerinin genellikle yöneten, gözleyen, karar veren, disiplinli, emir veren ve yetki sahibi kişiler olarak tanımlandığı belirtilmiştir. 
Araştırmacilar bu durumu okul yöneticilerinin daha çok bürokratik ve otoriter özelliklerinin ön plana çıkması olarak yorumlamaktadır.

Çobanoğlu ve Gökalp 'in (2015) öğretmen adaylarının okul müdürüne ilişkin metaforik algılarını inceledikleri çalışma sonuçları ise " baba, anne, aslan, çoban, diktatör" metaforlarının okul müdürleri için en fazla kullanılan metaforlar olduğunu göstermektedir.

Tüzel ve Kalyon (2017) tarafından sınıf öğretmeni adaylarının okul yöneticilerine ilişkin metaforları adlı çalışma sonuçları ise okul yöneticilerine yönelik üretilen metaforların genellikle yönetme ve sorumluluk, yetki, otorite sahibi olma gibi görev algısına ilişkin olduğunu ortaya koymaktadır. Araştırmanın dikkat çeken bir diğer sonucu ise sınıf öğretmeni adaylarının okul yöneticilerine yönelik imaj ve kişilik algılarının tamamen olumsuz öğelerden oluşmasıdır.

Özetle, yönetici metaforlarına ilişkin yurtiçi araştırmalar incelendiğinde; "lider", "otorite", "baba", "aile reisi", "anne", "kral", "patron" ve "kraliçe arı metaforlarının en sık tekrarlanan metaforlar olduğu görülmektedir. Yapılan araştırmalar incelendiğinde; metaforların otorite temsilcisi (kontrol eden kişi, otoriter, kraliçe arı (beğ), kral, patron, baskıcı, korkutucu, yasakçı, , öğrencilerle konuşmayan, yüzü gülmeyen, çatık kaşl, komutan, sert, diktatör, aslan, çoban, yasakçı, kuralcı) ve lider (lider, danışman, orkestra şefi, güvenilir, güce sahip, gemi kaptanı, güneş, çerçeve, koruyucu, aile reisi, anne, baba, bilgili, düzenleyici ve yol gösterici, beyin, arkadaş, , merkez, google, çatı, sorun çözücü, kaynaştırıcı, araştırmacı, yönetmen, , koç, eğitim uzmanı) temaları altında toplandığı görülmektedir. Bu temalardan yola çıkarak Türkiye'de liderliğin okul paydaşları tarafından yöneticilerin taşıması gereken bir özellik olarak tanımlandığını söylemek mümkündür.

\section{Sonuç}

Eğitim kurumlarının açı sistemler olması değişen dünya koşullarından etkilenmelerine ve yöneticilerden beklenen davranış rollerinin değişmesine sebep olmaktadır. Yönetici kavramının alan yazında kullanılmaya başlandığ1 1920'li yıllara kadar yönetim ve öğretim kavramları birlikte kullanmakta, okul yöneticisi öğretim, evrak ve hizmet işleri gibi okulun her şeyinden sorumlu tutulmakta idi. Toplumsal gelişmeler sonucunda artan okul ihtiyaC1 ve bu ihtiyacın okulların büyümesine neden olması "eğitim yöneticisi" 
kavramının doğmasına neden oldu. 1900'lü yıllarda ortaya çıkan yönetimsel verimlilik kavramı ise yöneticinin görev ve sorumluluklarının daha karmaşık bir hal almasına neden oldu.

Görev ve sorumlulukları giderek artan yönetici 21. yüzyıla gelindiğinde değişim yöneticisi, kurumsal lider, değişim ajanı, insan kaynakları yöneticisi, problem çözücü, hesap verebilirlik politikaların yerine getiren, liderlik özelliklerine sahip birey olarak anılmaya başlandı. Yöneticilik görevinin değişen tanımı yönetici rollerinin de değişiklik göstermesine neden oldu. Bu çok görevlilik yöneticilerin liderlik görevlerini anlamamaları ve birlikte çalıştıkları insanlar açısından farklı değerlendirilmeleri ile sonuçlandı. Değişen yönetici rollerine rağmen değişmemesi beklenen davranış rolleri yöneticilik anlayışının daha da karmaşık bir hal almasına neden oldu. Nitekim geçtiğimiz yüzyılda kaynakları düzenlemeleri, okuldaki oyun alanını güvenli hale getirmeleri, bütçeyi düzenlemeleri ve çevre ile iyi ilişkiler kurmaları beklenen yöneticilerden 21. yüzyılda bunların yanı sıra iş görenleri ile iyi bir iletişim içerisinde olmaları, eğitimin mükemmel olması için veri toplamaları, analiz etmeleri ve uygulamaları beklenmektedir. Kısaca, yönetici metaforları yöneticilerin değişen rol tanımlarına paralel bir şekilde değişim göstermektedir.

Yönetici metaforlarının tarihsel gelişimini incelerken, bu gelişimin yabancı alan yazına dayandığını göz önünde bulundurmak gerekmektedir. Nitekim yönetim alanında veya yönetime ilişkin olarak Türk düşünürleri ve devlet adamları tarafından yazılmış zengin eserlere (Bursalığlu, 2014) rağmen Türkiye'de yönetici metaforları konusunda yapılan çalışmalar çok eski tarihlere dayanmamaktadır. Bununla birlikte Türkiye'de yönetici yetiştirme sürecine ve okul yöneticilerine ilişkin çalışmaların belirli zaman aralıkları çerçevesinde incelenmesi ve bu dönemlerin baskın metaforlarının ortaya çıkarılması da mümkündür. Ayrıca yönetici metaforlarında "triangülasyon" yönteminin kullanılması da konuya ilişkin daha geniş bilgi edinimini sağlayacaktır. 
EXTENDED ABSTRACT

\section{An Analysis Of School Principalshıp Metaphors From Past To Present \\ * \\ Hilal Erkol \\ Ankara University}

Adolescence is a period in which biological, social and psychological changes occur. Although it has an important place in human life, it can be characterized as a period of time that diffuses into the process and causes individuals (adolescents) to experience different emotions at the same time, not the changes that take place.

In recent years, programs to increase adolescents' psychological resilience and preventive mental health skills - especially abroad - have been developed (see Brink and Wissing, 2012; Edwards, Mumford and SerraRoldan, 2007; Ricard et al., 2018) and different models of therapy have been used. When the literature is examined, it has been noted that DBT is one of the therapies used with adolescents in experimental studies. Validation and mindfulness are the core values of DBT. Mindfulness means being aware of the present and managing the emotions and thoughts in a healthy way. Validation is related to the environment in which the adolescent lives. It means accepting thoughts and feelings radically instead of opposing them.

Dialectic Behavior Therapy (DBT) is one of the third wave therapies and has been experimentally tested with different groups. This approach, which was developed by Marsha Linehan in the early 1990s to improve patients with borderline personality disorder, was later used to deal with different problems and behavioral issues. In the course of time, DBT was used in different settings (hospitals, schools, private clinics), groups (adolescents, adults), and gender. When we look at the development process of DBT, we can see that Linehan's personal experiences are very effective. After a difficult adolescence and young adulthood (18 years old, diagnosed with schizophrenia, hospitalization for 26 months, self-harm, at least two suicide attempts), Marsha Linehan became interested in psychology and received psychology education. In the following years, she started working with 
individuals diagnosed with borderline personality disorder (Sargin and Sargin, 2015).

Linehan (1993) argued that problematic behavior of individuals who are emotionally disturbed is affected by a number of biological and environmental factors. Specifically, the person's biological weakness and the environment in which he or she is (who does not approve of anything, does not value) paves the way for emotional disorder and triggers possible future problems (Rathus and Miller, 2018).

The word of dialectic comes from Greek and means "discussion, conversation." In the therapy, it means that two opposing ideas or phenomena can be correct and that a new thought can be synthesized (Linehan, 1993). The adolescent has to accept the situation in order to change and benefit from DBT. The function of approval is to normalize the events and situations in which the client has difficulty accepting with the support of the counselor in the counseling.

DBT can be implemented in four different ways: a) individual therapy, b) psychoeducation groups based on skills training, c) telephone interviews and d) consultation team meetings (Linehan, 2015a). DBT has a four-stage treatment process. Each stage has its own goals. The steps are numbered 1 through 4 depending on the severity of the problems the client has. A client can be diagnosed in only one stage or in two stages at the same time. It is the consultant and consultation team that will make this decision.

The aim of this study is to introduce the theory, concepts and application areas of DBT, which is included in third wave therapies and whose usage has been rapidly spreading with adolescents in recent years. Another goal of the study is to provide a reference resource for future studies with adolescents. DBT has been shown to be successful in evidence-based studies, especially with suicidal, self-injurious behavior, depression, adolescents with poor communication skills, anger control and behavioral problems, and emotion disorder. There is no evidence-based study using DBT conducted with adolescents in Turkey yet. It is strongly recommended that this kind of study be done in the future.

\section{Kaynakça / References}

Akan, D., Yalçın, S., ve Yıldırım, İ. (2014). Teachers' methaphoric impressions related to'School Manager'. Elementary Education Online, 13(1), 169-179. 
Akan D., Yalçın S. ve Yıldırım İ. (2013). Teachers' mental/metaphorical perceptions to education inspector. Mevlana International Journal of Education (MIJE), 3(1), 58-67.

Arnett, R. C. (1999). Metaphorical guidance. Administration as building and renovation. Journal of Educational Administration, 37 (1), 80-89.

Arslan, M. M. ve Bayrakçı, M. (2006). Metaforik düşünme ve öğrenme yaklaşımının eğitim-öğretim açısından incelenmesi. Milli Ĕ̆itim, 35(171), 100-108.

Ash, R. C. ve Persall, J. M. (2000). The principal as chief learning officer: Developing teacher leaders. NASSP bulletin, 84(616), 15-22.

Audinot, E. S. (1994). The metaphoric language of a principal. Doctoral dissertation, Walden University. http://www.mkutup.gov.tr/tr/Sayfalar/EVeri-Tabanlari/ProQuest-Dissertations-Theses-Global.aspx adresinden alınmıştır.

Aydın, İ. S. ve Pehlivan, A. (2010). Türkçe öğretmeni adaylarının öğretmen ve öğrenci kavramlarına ilişkin kullandıkları metaforlar. Turkish Studies International Periodical For the Languages, Literature and History of Turkish or Turkic, 5(3), 818-842.

Balc1, A. (2007). Etkili okul. Okul geliştirme. Kuram, uygulama ve araştırma (4. Baskı). Ankara: Pegem A Yayıncllı.

Balc1, A. (2008). Türkiye' de eğitim yönetiminin bilimleşme düzeyi. Kuram ve Uygulamada Egitim Yönetimi Dergisi, 14(2), 181-209.

Balcı, A. (2010). Açıklamalı eğitim yönetimi terimleri sözlüğü (2. bask1). Ankara: Pegem Akademi.

Balcı, A. (2011). Eğitim yönetiminin değişen bağlamı ve eğitim yönetimi programlarına etkisi. Eğitim ve Bilim, 36(162), 196-208.

Bartel R. (1983). Metaphors and symbols: Forays into language. The USA: National Council of Teachers of English.

Baştan,A., Tetik, İ. ve Kasımay, C. (2014, Kasım). Okul müdürlerinin "Müdür" algılarının incelenmesi. 9. Ulusal Ĕ̆itim Yönetimi Kongresi içinde (s. 14-16). Kasım 2014, Ankara.

Beck, L. G. ve Murphy, J. (1993). Understanding the principalship: Metaphorical themes, 1920s-1990s. New York: Teachers College Press.

Blase ve Blase (1999) Principals' instructional leadership and teacher development. Educational Administration Quarterly, 35(3), 349-378.

Bodycott, P., Walker, A. ve Chi Kin, J. L. (2001).More than heroes and villains: preservice teacher beliefs about principals.Educational Re-search,43(1),15-31. 
Botha, E. (2004). Why metaphor matters in education. South African Journal of Education, 29(4), 431-444.

Bredeson, P. V. (1987). Languages of leadership: Metaphor making in educational administration. 16.11.2016 tarihinde http://eric.ed.gov/?id=ED294296 adresinden alınmıştır.

Budhal R. S. (2000). The impact of the principal's instructional leadership on the culture of teaching and learning in the school. MED dissertation, Univer-sity of South Africa, Pretoria.

Bursalığlu, Z. (2014). Eğitim yönetiminde teori ve uygulama. (12. Basım). Anka-ra: Pegem Akademi.

Bursalığlu, Z. (2008). Okul yönetiminde yeni yapı ve davranış. (14. Basım). Ankara: Pegem Akademi.

Bursaloğlu, Z. (2005). Eğitim yönetiminde teori ve uygulama. (8. Bask1). Ankara: Pegem Akademi.

Cerit Y. (2008). Öğretmen kavramıyla ilgili metaforlara ilişkin öğrenci, öğretmen ve yöneticilerin görüşleri. Türk Egitim Bilimleri Dergisi, 6(4), 693-712.

Çapan, B. E. (2010). Öğretmen adaylarının üstün yetenekli öğrencilere ilişkin metaforik algıları. Uluslararası Sosyal Araştırmalar Dergisi, 3(12), 140-154.

Çelik, H. (2016). Demokratik liderlik ve örgütsel güven ilişkisi: Balıkesir merkez ilçeleri örneği. Yüksek Lisans Tezi, Balıkesir Üniversitesi, Balıkesir. https://tez.yok.gov.tr/UlusalTezMerkezi// adresinden erişilmiştir.

Çobanoğlu, N. ve Gökalp, S. (2015). Öğretmen adaylarının okul müdürüne ilişkin metaforik algıları. Mustafa Kemal Üniversitesi Sosyal Bilimler Enstitüsü Dergisi, 12(31), 279- 295.

Day, C. Harris, A. Hadfield, M. Tolley, H. ve Beresford, J. (2000). Leading schools in times of change. Buckingham: Open University Press.

Denshire, S. (2002). Metaphors we live by: Ways of imagining practice. Qualitative Research Journal, 2(2), 28-46.

Dönmez, Ö. (2008). Türk eğitim sisteminde kullanılan yönetici metaforları. Yüksek Lisans Tezi, Erciyes Üniversitesi, Kayseri. https://tez.yok.gov.tr/UlusalTezMerkezi/ adresinden erişilmiştir.

Döş, İ. (2010). Aday öğretmenlerin müfettişlik kavramına ilişkin metafor algıları. Gaziantep Üniversitesi Sosyal Bilimler Dergisi, 9(3), 607-629.

Eren, A. ve Tekinarslan, E. (2013). Prospective teachers' metaphors: Teacher, teaching, learning, instructional material and evaluation concepts. International Journal of Social Sciences and Education, 3(2), 435-445. 
Firestone, W. A. ve Riehl, C. J. (2005). A new agenda for research in educational leadership. New York: Teachers College Press.

Frese, M. Beimel, S. ve Schoenborn, S. (2003). Action training for charismatic leadership: Two evaluations of studies of a commercial training modüle on inspirational communication of a vision. Personnel Psychology, 56(3), 671-697.

Gedikoğlu, T. (1997). Eğitim yönetimi. Dün, bugün ve 2000'li y1llara doğru. Ĕ̆itim Yönetimi, 3(3), 299-308.

Glanz, J. ve Neville, R. F. (1997). Educational supervision: Perspectives, issues, and controversies. Norwood, MA: Christopher-Gordon.

Goodwin, R., Cunningham, M., ve Eager, T. (2005). The changing role of the secondary principal in the United States: An historical perspective. Journal of Educational Administration and History, 37(1), 1-17.

Goldring, E. ve Greenfield, W. (2002). Yearbook of the national society for the society of education. http://onlinelibrary.wiley.com/doi/10.1111/j.17447984.2002.tb00001.x/epdf adresinden 08/01/2017 tarihinde alınmıştır.

Gökçe, A. T. ve Bülbül, T. (2014). Okul bir insan bedenidir: Meslek lisesi öğrencilerinin okul algılarına yönelik bir metafor çalışması. Eğitim Bilimleri Araştırmaları Dergisi, 4(1), 63-88.

Gürbüz, O. ve Mevlüt, G. (2006). Eğitim fakültesini yeni kazanan öğretmen adaylarının öğretmenlik mesleğine giriş dersini almadan önce ve aldıktan sonra öğretmenlik mesleği hakkındaki metaforlarının karşılaştırılması. Afyon Kocatepe Üniversitesi, Sosyal Bilimler Dergisi, 8(2), 293-309.

Hallinger, P. ve Heck, R. H. (1996). Reassessing the principal's role in school effectiveness: A review of empirical research, 1980-1995. Educational Administration Quarterly, 32(5), 2-42.

Harris, Ballenger ve Leonard (2004). Aspiring principal perceptions: are mentor principals modeling standards-based leadership?, Mentoring and Tutoring, 12(2), 155-172.

Heinrich, C. Y. (2009). Third-party governance under No Child Left Behind: Accountability and performance management challenges. Journal of Public Administration Research and Theory, 20(1), 59-80.

Institute for Educational Leadership (2000). Leadership for student learning: Reinventing the principalship. Washington, DC: Author.

Kafka, J. (2009). The principalship in historical perspective. Peabody Journal of Education, 84(3), 318-330. 
Knezevich, S. J. (1969) Administration of public education (2nd ed.). New York: Harper \& Row.

Koçak, Ö. (2011). Okul müdürlerinin, öğrencilik, öğretmenlik ve müdürlük dönemlerindeki okul yöneticiliğine ilişskin metaforik algıları. Yüksek Lisans Tezi, Gaziosmanpaşa Üniversitesi, Tokat.

Konan, N. ve Yılmaz, S. (2017). Metaphoric perceptions of primary school principals regarding 'School Principal'. In ( R. Efe, I. Koleva, E. Ata-soy, V. Kotseva Ed.) Current Trends in Educational Sciences (p. 163-174). Sofia: St. Kliment Ohridski University Press.

Lakoff, G. ve Johnson, M. (2010). Metaforlar. Hayat, anlam ve dil. İstanbul: Paradigma Yayıncilik.

Leavy, A. M., McSorley F. A. ve Bote, L. A. (2007). An examination of what metaphor construction reveals about the evolution of preservice teachers' beliefs about teaching and learning. Teaching and Teacher Education, 23 (7), 1217-1233.

Leithwood, K., Harris A. ve Hopkins, D. (2008). Seven strong claims about successful school leadership. School Leadership and Management, 28(1), 27-42.

Linn G. B., Sherman R. ve Gill P. B. (2007). Making meaning of educational leadership: The principalship in metaphor. NASSP Bulletin 91(2), 161171.

Lord, R. G. ve Brown, D. J. (2001). Leadership, values, and subordinate selfconcepts. The Leadership Quarterly, 12(2), 133-152.

Martinez, M. A., Sauleda, N. ve Huber, G. L. (2001). Metaphors as blueprints of thinking about teaching and learning. Teaching and Teacher Education, 17(8), 965-977.

Massengil, D. S. ve Mahlios, M. (2008). Pre servise teachers' metaphors of teaching and literacy. Reading Psychology, 29 (1), 31-60.

Monreo, C. E. (2003). An analysis of principalship metaphors at the beginnnig of the new millennium. Doctor of education, Available at ProQuest Dissertations and Theses.

Nalçacı, A. ve Bektaş, F. (2012). Öğretmen adaylarının okul kavramına ilişkin algıları. Ahi Evran Üniversitesi Kırşehir Eğitim Fakültesi Dergisi (KEFAD), 13(1), 239-258.

Morgan G. (1998). Yönetim ve örgüt teorilerinde metafor (çev. G. Bulut). Sage Publications. 
Nwagwu, E. C. (1998). How community college administrators can improve teaching effectiveness. Community College Journal of Research and Practice, 22(1), 11-19.

Ovando, M. N. ve Cavazos, M. (2004). Principals' instructional leadership in successful hispanic majority high schools. A Journal for the ScholarPractitioner Leader, 2(3), 7-24.

Örücü, D. (2014). Öğretmen adaylarının okul, okul yönetimi ve Türk eğitim sistemine yönelik metaforik algıları. Kuram ve Uygulamada Ĕ̆itim Yönetimi, 20(3), 327-358.

Özdemir, M. (2012). Lise öğrencilerinin metaforik okul algılarının çeşitli değişkenler bakımından incelenmesi. Eğitim ve Bilim, 37(163), 96-109.

Özden, Y. (1999). Eğitimde dönüşüm. Eğitimde yeni değerler (2. Baskı). Ankara: Pegem A Yayıncilık.

Özmen, F. ve Sönmez, Y. (2007). Değişim sürecinde eğitim örgütlerinde değişim ajanlarının rolleri. Firat Üniversitesi, Sosyal Bilimler Dergisi, 17(2), 177-198.

Palmquist, R. A. (2001). Cognitive style and users' metaphors for the web: An exploratory study. The Journal of Academic Librarianship, 27(1), 24-32.

Peterson, K. D. ve Deal, T.E. (1998). How leaders influence the culture of schools. Educational Leadership, 56(1), 1-5.

Pierce, P. R. (1935). The origin and development of the public school principalship. The USA: Chicago, IL, University of Chicago Press.

Rousmaniere, K. (2007). Presidential address: Go to the principal's office: Toward a social history of the school principal in North America. History of Education Quarterly, 47(1), 1-22.

Saban, A. (2004). Giriş düzeyindeki sınıf öğretmeni adaylarının "Öğretmen" kavramına ilişkin ileri sürdükleri metaforlar. Türk Eğitim Bilimleri Dergisi, 2(2), 131-155.

Saban, A. (2008). Okula ilişkin metaforlar. Kuram ve Uygulamada Ĕ̆itim Yönetimi Dergisi, 55(55), 459-496.

Saban A. (2009). Öğretmen adaylarının öğrenci kavramına ilişkin sahip oldukları zihinsel imgeler. Türk Ĕ̆itim Bilimleri Dergisi, 7(2), 281-326.

Samier, E. (2006). Educational administration as a historical discipline: An apologia pro vita historia. Journal of Educational Administration and History, 38(2), 125- 139. 
Schechter,C, Shaked, H., Ganon-Shilon, S. ve Goldratt, M. (2016). Leadership metaphors: School principals' sense-making of a national reform. Leadership and Policy in Schools, 04.01.2017 tarihinde http://www.tandfonline.com/loi/nlps20 adresinden erişilmiştir.

Shaw, D. M. ve Mahlios, M. (2008). Pre-service teachers' metaphors of teaching and literacy. Reading Psychology, 29(1), 31-60.

Skinner, C. F., Skinner, C. F., Skinner, A. L. ve Cashwell, T. H. (1999). Using inter-dependent contingencies with groups of students: Why the principal kissed a pig?. Educational Administration Quarterly, 35(5), 806820.

Smith,W. ve Andrews, R. (1989). Instructional leadership: How principals make a difference. Alexandria, VA: Association for Supervision and Curriculum Development.

Stam, D. A., Knippenberg, D. V. ve Wisse, A. B. (2010). The role of regulatory fit in visionary leadership. Journal of organizational behaviour, 31(4), 499-518.

Strike, K. A. (2000). Schools as communities; Four metaphors, Three models and a dilemma or two. Journal of Philosophy of Education, 34(4), 617-642.

Şişman, M. (2010). Türk eğitim sistemi ve okul yönetimi. Ankara: Pegem Akad-emi

Taymaz, H. (2009). Ilköğretim ve Ortaöğretim müdürleri için okul yönetimi. (9. Bask1), Ankara: Pegem Akademi.

Tengilimoğlu, D. (2005). Kamu ve özel sektör örgütlerinde Llderlik davranışı özelliklerinin belirlenmesine yöelik bir alan çalışması. Elektronik Sosyal Bilimler Dergisi, 4(14), 1-16.

Tok, T. N. (2013). Who is an education supervisor? A guide or a nightmare?, International Journal of Social Sciences and Education, 3(3), 752-769.

Töremen, F. ve Döş, İ. (2009). İlköğretim öğretmenlerinin müfettişlik kavramına ilişkin metaforik algıları. Kuram ve Uygulamada Eğitim Bilimleri, 9(4), 1973-2012.

Trnavcevic, A. ve Vaupot, S. R. (2009). Exploring aspiring principals' perceptions of principalship. A Slovenian case study. Educational Management Administration \& Leadership, 37(1) 85-105.

Turhan, M. ve Yaraş, Z. (2013). Öğretmen ve öğrencilerin öğretmen, disiplin, müdür, sınıf kuralları, ödül ve ceza kavramlarına ilişkin metafor algıları. Firat Üniversitesi Sosyal Bilimler Dergisi, 23(1), 129-145.

Tüzel, E. ve Kalyon, D.Ş. (2017). Sınıf öğretmeni adaylarının okul yöneticilerine ilişkin algıları. Turkish Studies, 12(33), 501-522. 
Ünal A. , Yıldırım A. ve Çelik M. (2010). İlköğretim okulu müdür ve öğretmenlerinin velilere ilişkin algılarının analizi. Selçuk Üniversitesi Sosyal Bilimler Enstitüsü Dergisi, 23, 261-272.

Wagenheim, G. Clark, R. ve Crispo, A.W. (2009). Metaphorical mirror: Reflecting on our personal pursuits to discover and challenge our teaching practice assumptions. International Journal of Teaching and Learning in Higher Education, 20(3), 503-509.

Yalçın, M. (2011). İlköğretim okullarında okul müdürlerine ilişkin metaforik algılar. Yüksek Lisans Tezi, Gaziosmanpaşa Üniversitesi, Tokat.

Yıldırım, N. ve Uğur, M. (2011). Öğrencilerin algısından okul müdürü imgelerinin karikatürize ifadeleri. Kastamonu Ĕ̆itim Dergisi, 19(2), 409-426.

Yörük, S. ve Kocabaş, İ. (2001). Eğitimde demokratik liderlik ve iletişim. Fırat Üniversitesi Sosyal Bilimler Dergisi, 11(1), 225-234.

Zhao, H., Coombs, S., ve Zhou, X. (2010). Developing professional knowledge about teachers through metaphor research: facilitating a process of change. Teacher Development, 14(3), 381-395.

Kaynakça Bilgisi / Citation Information

Erkoç, H. (2020). Geçmişten günümüze yönetici metaforlarının analizi. OPUS-Uluslararası Toplum Araştırmaları Dergisi, 15(24), 3012-3042. DOI: 10.26466/opus.605482 